\title{
The State of Social Studies in Basic Education Schools in Oman
}

\author{
Saif Al-Maamari ${ }^{1}$, Mohammed Al-Nofli ${ }^{2} \&$ Zainab Al-Gharibi ${ }^{3}$ \\ ${ }^{1}$ College of education, Sultane Qaboos University, Muscat, Sultanate of Oman \\ ${ }^{2}$ Ministry of Education, Muscat, Oman \\ 3 Ministry of Education, Minister's Office, Muscat, Oman \\ Correspondence: Saif Al-Maamari, College of education, Sultane Qaboos University, B.O 32 Muscat, Sultanate of \\ Oman. Tel: 968-9711-1139. E-mail: saifn@squ.edu.om; malnofli@moe.om
}

$\begin{array}{lc}\text { Received: October 5, } 2013 & \text { Accepted: February 4, } 2014 \quad \text { Online Published: March 31, } 2014 \\ \text { doi:10.5539/ass.v10n7p213 } & \text { URL: http://dx.doi.org/10.5539/ass.v10n7p213 }\end{array}$

\begin{abstract}
This study explored the state of social studies in basic education schools in the current reform. Particularly, it explored teachers' preferred rationales for teaching social studies, content areas emphasized in the social studies curriculum, instructional methods used by teachers, and the importance of social studies and other school subjects. Data were gathered by surveys from 451 social studies teachers from all Omani governorates. Findings showed that teachers supported all rationales for teaching social studies in schools. The most emphasized topics were Omani history, geography of Oman, rights and duties of citizens, population education, geography of the Arab world, and environmental education. There was a significant progress in implementing student-centered instructional methods. Unfortunately, social studies was not regarded as an important school subject. Implications of the study were discussed.
\end{abstract}

Keywords: social studies, teachers' perceptions, social sciences, citizenship education, Oman, basic education

\section{Introduction}

Education in Oman has undergone significant changes since the implementation of the Basic Education Reform in 1998. Some of the major features of the current reform include implementing student-centered activities, using a variety of formative assessment methods, revising school curricula and materials to include relevant knowledge and skills that prepare students for life and work, introducing new subject areas such as information technology and life skills, reducing class size, and equipping schools with learning resource centers (Ministry of Education [MOE], 2006). In recent years, there has been an argent need to investigate various issues facing school subjects to help policy makers and curriculum designers consider future revisions. Therefore, the purpose of the present study was to explore the state of social studies in basic education schools in the current reform.

\section{Social Studies in the Basic Education Stage in Oman}

Social studies is one of the primary vehicles for the education of citizenship (Engle \& Ochoa, 1988; Print \& Smith, 2000; Sears, 1994). According to the National Council for the Social Studies [NCSS] (1994), the primary purpose of social studies is "to help young people develop the ability to make informed and reasoned decisions for the public good as citizens of a culturally diverse, democratic society in an interdependent world" (p. 3). Social studies subject fosters social participation, active student engagement, and inquiry learning. It aims to prepare responsible citizens by imparting citizenship attitudes, values, and critical thinking skills (Adeyinka, 2000).

Social studies subject in Oman provides key knowledge, skills, values, and dispositions that help students become informed citizens. Among social studies goals are to help students appreciate Omani heritage and values, understand rights and responsibilities of citizens, understand locations and environments in Oman and other countries, develop positive attitudes towards the environment, and understand some contemporary challenges facing Omani society and the larger global community (MOE, 2005).

Social studies in the basic education stage (grades 1-10) is a required subject for students in grade three through ten. The curriculum is organized around three main areas: geography, history, and civics. In the post-basic education stage (grades 11-12), the social studies program offers two required courses (This is My Homeland 1 $\& 2$ ), which focus on a variety of topics related to Omani society, and four elective courses (Ministry of 
Education, 2007):

1) Islamic civilization (grade 11)

2) Economic geography (grade 11)

3) The world around me (grade 12)

4) Geography and modern technologies (grade 12)

Although social studies teaching before the implementation of the Basic Education Reform was characterized by the dominance of traditional teaching methods and limited learning materials (Al-Riyami, 1996), there are a number of changes in the current reform. For example, a recent study by Al-Nofli (2013) indicated that the dominant instructional strategies in geography classes were discussion, the use of current events, cooperative learning, inquiry, and projects. In terms of instructional resources, findings of the study showed that atlases, maps, globes, and the Internet dominated geography classes. Recently, topics on geographic information systems (GIS) are included in the geography curriculum for grade 12 (MOE, 2009).

There have been a variety of studies which have provided insight into some aspects of social studies in the current reform. In a study assessing the perceptions of social studies student teachers and their tutors about citizenship education, AlMaamari (2009) found that participants viewed citizenship education as a means to build national pride and unity. Among the perceived important goals of citizenship education were to provide students with knowledge about their country and its political, economic, and cultural systems; appreciate the heritage and culture of Oman; understand rights and responsibilities of citizens; develop patriotic and loyal citizens; and develop critical thinking and problem solving skills. The content was perceived to focus more on Omani history and geography, structure of the government, Omani traditions and customs, and values that promote loyalty, respect, and love of the country.

Despite recent developments in social studies in Omani schools, there are a number of issues facing the subject in the current reform. For example, in a survey on Omani students' attitudes toward social studies, Al-Gharibi (2008) found that students did not see social studies as useful for a career or helpful to learn about their own country or being related to their own lives. This can be a result of several factors, including social studies content. As Al-Nofli (2010) reported, the social studies curriculum repeated important topics studied in earlier grades, with little emphasis on the study of world countries and cultures. In addition, recent studies indicated that historical and critical thinking skills were not adequately applied in social studies classes (Al-Hamdi, 2013; Al-Malki, 2013). With regard to global issues, the social studies curriculum focused more on environmental issues, economic issues, and natural disasters, but lacked political issues (Al-Rabani, 2009). Al-Sarmi (2012) found several challenges to teaching global citizenship, including the lack of field trips to study topics related to global citizenship, lack of learning activities in the curriculum, and teachers' workload.

In a study on the use of school libraries by Omani teachers, Bouazza and Al-Mufaraji (2005) found a low use of school libraries. This was attributed to a number of reasons, including shortages of library resources: print, audiovisual, and electronic materials. Further, a recent report by the Ministry of Education indicated that the use of information and communication technologies (ICT) to support teaching and learning remains limited and uneven in public schools. Application of ICT in classroom requires a greater focus on building teacher pedagogical skills (MOE, 2012).

In terms of instructional time, there is an inadequate emphasis on social studies in Omani schools. For example, the instructional time devoted to the subject is approximately three to four class periods per week across basic education grade levels. This appears to be one of the major challenges facing social studies in many countries. As Leming, Ellington, \& Schug (2006) indicated, the majority of elementary teachers in the United States devote less than one hour a day to social studies.

Since the implementation of the Basic Education Reform in 1998, no comprehensive research study has been conducted on social studies. The current study sought to provide an understanding of the state of social studies from social studies teachers' perspectives. In particular, the study examined teachers' perceptions on the state of social studies in terms of rationales for teaching social studies, content areas emphasized in the social studies curriculum, instructional methods used in teaching social studies, and important subject areas taught in schools.

\section{Research Method}

\subsection{Participants}

This study involved a population of all social studies teachers in basic education schools of the second cycle (grades 5-10) in all Omani governorates. This population comprised (1652) social studies teachers (764 males 
and 888 females) distributed in 381 basic education schools of the second cycle (MOE, 2011).

\subsection{Instrumentation}

To explore the state of social studies in Omani schools, we designed a survey consisting of five parts: demographic data of participants, preferred rationales for teaching social studies, content areas emphasized in social studies curriculum, instructional methods used by teachers, and the importance of social studies in schools. The survey items were developed from our experience in social studies and from related literature (National Council for Social Studies, 1994; Leming et al. 2006). A panel of educators with specialties in social studies and research methods reviewed the survey. Based on their recommendations, modifications we made to the survey. It was pilot tested with a group of teachers and modified accordingly. Data were collected during the spring semester of 2011, following approval of the study by the MOE. Statistical analyses included descriptive statistics such as means, standard deviations, and percentages.

\section{Results}

This section includes demographic characteristics of teachers and their perceptions of the state of social studies in basic education schools.

\subsection{Demographics}

Of 1652 surveys sent to social studies teachers, 451 surveys were completed and returned for a response rate of (27.3\%). The teachers who responded were 227 females $(50.3 \%)$ and 224 males $(49.7 \%)$. The Bachelor of Education was the most commonly held degree $(71.1 \%)$, followed by a Bachelor of Arts and Certificate in Education (20.6\%), a two-year Diploma in Education (6.7\%), and a Master's degree (1.6\%). The teachers were specialized in geography $(54.9 \%)$, history $(33.6 \%)$, general social studies $(8.6 \%)$, and other specializations $(2.9 \%)$. In terms of teaching experience, $35.7 \%$ of the teachers had one to five years, $34.4 \%$ had six to ten years, $20.7 \%$ had eleven to fifteen years, and $9.2 \%$ had over 16 years.

\subsection{Rationales for Teaching Social Studies}

The second part of the survey asked respondents to indicate the importance of eight rationales for why social studies should be taught in basic education schools. Respondents were asked to rate their responses on a scale ranging from one (unimportant) to four (very important).

As shown in Table 1, the teachers supported all rationales suggested in this study. The top three important rationales were social studies helps students acquire core values and principles of the Omani society, helps students acquire knowledge and skills from history and the social sciences, and helps students study important issues facing Omani society.

Table 1. Important rationales for teaching social studies in schools

\begin{tabular}{lccc}
\hline Rationales for teaching social studies & $N$ & $M$ & $S D$ \\
\hline Acquire core values and principles of Omani society. & 451 & 3.75 & 0.56 \\
Acquire knowledge and skills from history and the social sciences. & 451 & 3.64 & 0.59 \\
Study important issues facing Omani society. & 448 & 3.49 & 0.73 \\
Learn about countries and cultures around the world. & 451 & 3.47 & 0.69 \\
Cope with issues of contemporary life. & 446 & 3.40 & 0.77 \\
Participate in social and political affairs of society. & 445 & 3.22 & 0.84 \\
Acquire critical thinking skills. & 449 & 3.12 & 0.84 \\
Acquire skills that help to get career opportunities in future. & 448 & 3.05 & 0.92 \\
\hline
\end{tabular}

\subsection{Social Studies Content}

The third part of the survey asked respondents to indicate the degree of emphasis given to a variety of topics in social studies curriculum for basic education schools. Respondents were asked to rate their responses on a scale ranging from one (no emphasis) to four (extremely heavy emphasis). As shown in Table 2, the most emphasized topics were Omani history, geography of Oman, rights and duties of citizens, population education, geography of the Arab world, and environmental education. 
Table 2. Content areas emphasized in social studies curriculum

\begin{tabular}{lccc}
\hline Content areas & $N$ & $M$ & $S D$ \\
\hline Omani history & 451 & 3.21 & 0.83 \\
Geography of Oman & 448 & 3.19 & 0.87 \\
Rights and duties of citizens & 444 & 2.94 & 0.90 \\
Population education & 451 & 2.92 & 0.91 \\
Geography of the Arab world & 441 & 2.90 & 0.85 \\
Environmental education & 451 & 2.88 & 0.89 \\
Issues of the Omani society & 451 & 2.77 & 0.92 \\
Omani institutions & 450 & 2.75 & 0.92 \\
Community service & 443 & 2.73 & 0.92 \\
Family education & 451 & 2.70 & 0.89 \\
Islamic history & 451 & 2.63 & 0.96 \\
World geography & 451 & 2.59 & 0.92 \\
Arab history & 451 & 2.58 & 0.87 \\
International relations & 451 & 2.53 & 0.90 \\
World history & 451 & 2.52 & 0.90 \\
Arab culture & 446 & 2.42 & 0.87 \\
World economic systems & 451 & 2.41 & 0.91 \\
Science and society & 447 & 2.41 & 0.93 \\
Geography of the Islamic world & 451 & 2.40 & 0.92 \\
World culture & 451 & 2.35 & 0.88 \\
Consumer education & 443 & 2.33 & 0.94 \\
Career education & 451 & 2.21 & 0.91 \\
Law and society & 451 & 2.20 & 0.98 \\
Global education & 439 & 2.02 & 0.89 \\
\hline
\end{tabular}

\subsection{Social Studies Teaching}

The fourth part of the survey asked respondents about (a) instructional methods commonly used in social studies teaching, (b) social studies skills emphasized in classroom, and (c) teacher participation in professional development activities (e.g. attending workshops and conferences) to support social studies teaching. In terms of instructional methods commonly used in social studies teaching, findings showed that the most widely used methods were discussion, current events, cooperative learning, problem solving, story, and brain storming (Table $3)$. 
Table 3. Instructional methods used by social studies teachers

\begin{tabular}{lccc}
\hline Instructional methods & $N$ & $M$ & $S D$ \\
\hline Discussion & 447 & 3.70 & 0.63 \\
Using current events & 451 & 3.51 & 0.67 \\
Cooperative learning & 448 & 3.38 & 0.73 \\
Problem solving & 451 & 3.26 & 0.78 \\
Story & 449 & 3.07 & 0.80 \\
Brain storming & 451 & 3.04 & 0.77 \\
Role playing & 451 & 2.91 & 0.91 \\
Discovery learning & 443 & 2.90 & 0.82 \\
Inquiry & 451 & 2.80 & 0.87 \\
Group projects & 451 & 2.77 & 0.93 \\
Individual projects & 449 & 2.77 & 0.93 \\
Lecture & 451 & 2.76 & 0.90 \\
Case study & 441 & 2.40 & 0.79 \\
Debate & 444 & 2.11 & 0.87 \\
Field study & 451 & 2.04 & 0.92 \\
Guest speakers & 451 \\
\hline
\end{tabular}

In reference to skills emphasized in social studies classes (Table 4), findings indicated that maps and globes, thinking skills, and reading were the most emphasized skills.

Table 4. Skills emphasized in social studies instruction

\begin{tabular}{lccc}
\hline Social studies skills & $N$ & $M$ & $S D$ \\
\hline Maps and globes & 446 & 3.59 & 0.65 \\
Thinking skills & 448 & 3.37 & 0.67 \\
Reading (reading scientific texts and literature) & 451 & 3.21 & 0.82 \\
Human relations & 444 & 2.93 & 0.84 \\
Research papers/reports & 451 & 2.78 & 0.90 \\
Decision making & 451 & 2.77 & 0.85 \\
Participation in society & 442 & 2.74 & 0.85 \\
\hline
\end{tabular}

In terms of teacher participation in professional development activities to support social studies teaching, findings indicated very low participation. As indicated in Table 5, 86\% of the teachers participated in $0-3$ activities in the last two academic years.

Table 5. Number of professional development activities offered for teachers

\begin{tabular}{lcc}
\hline No. of professional development activities & No. of teachers & Percentage \\
\hline 0 & 170 & 39.1 \\
$1-3$ & 204 & 46.9 \\
$4-6$ & 38 & 8.7 \\
$7-9$ & 14 & 3.2 \\
$10-12$ & 2 & 0.5 \\
More than 12 & 7 & 1.6 \\
Total & 435 & 100 \\
\hline
\end{tabular}




\subsection{Importance of Social Studies}

The last part of the survey asked respondents to indicate the degree of importance given to social studies and other school subjects (Islamic studies, Arabic, mathematics, science, and English). Respondents were asked to rate their responses on a scale ranging from one (extremely important) to six (extremely unimportant). As indicated in Table $6,51.9 \%$ of the teachers rated mathematics as important and extremely important, followed by Arabic language (49.8\%), and Islamic studies (36.6\%). Unfortunately, social studies ranked last in terms of importance.

Table 6. Importance of school subjects

\begin{tabular}{lcc}
\hline School subjects & No. of teachers* & Percentage \\
\hline Mathematics & 230 & 51.9 \\
Arabic language & 222 & 49.8 \\
Islamic education & 164 & 36.6 \\
English language & 128 & 28.9 \\
Science education & 110 & 24.8 \\
Social studies & 35 & 7.9 \\
\hline
\end{tabular}

* Number of teachers who ranked each subject as important and extremely important.

This part also included a question asking respondents to indicate student interest in social studies. Respondents were asked to rate their responses on a scale ranging from one (no interest) to three (high interest). Approximately half of the teachers (48.6\%) reported that their students had high interest in social studies and $47.5 \%$ said somewhat of interest. Only, 3.8 of the teachers reported no interests.

\section{Discussion}

The purpose of this study was to explore the state of social studies in basic education schools in Oman. Particularly, the study explored teachers' preferred rationales for teaching social studies, teachers' views on content areas that are emphasized in the social studies curriculum, teachers' views on their instructional methods, and teachers' views on the importance of social studies and other subjects in schools. Findings of the study showed that teachers supported all rationales for teaching social studies in schools. Clearly, this finding reflects teachers' positive views on the importance of social studies in developing knowledge, skills, values, and dispositions associated with citizenship.

Although social studies curriculum should include a wide range of content areas from the social sciences, humanities, and other fields (NCSS, 1994), it seems that there is much emphasis on topics related to Oman (e.g., history, geography, roles and responsibilities of citizens). Among the topics that received less emphasis include global education and world cultures. It is important that global education should be a major focus of social studies. As the NCSS (1994, p.7) pointed out, students should be helped "to construct a global perspective that includes knowledge, skills, and commitments needed to live wisely in a world that possesses limited resources and that is characterized by cultural diversity".

In examining teachers' views on their instructional methods, the most widely used methods were discussion, the use of current events, cooperative learning, brainstorming, and inquiry. As with Al-Nofli's (2013) findings, the most widely used methods were those methods that adopt student-centered strategies, such as discussion, cooperative learning, projects, and inquiry. Clearly, this finding supports efforts made by the MOE to shift away from teacher-centered learning to student-teacher learning and create a learning environment that encourages students to take responsibility for their own learning (MOE, 2006).

One of the striking findings of this study was that teachers reported having limited opportunities to participate in professional development opportunities. The majority of teachers (86\%) participated in less than four programs over the last two years (see Table 5). In fact, it has been noted that there are several issues facing teacher training in Oman, including the training is over-theoretical, the training is delivered in a didactical manner and does not respond to teachers' issues and concern, and the trainers are not sufficiently expert in the content (Ministry of Education, 2012). With the lack of training opportunities, teachers are less likely to be aware of recent development in content knowledge and recent trends in teaching and learning.

Despite its vital roles in promoting citizenship, social studies received the lowest rank in terms of importance. 
Unsurprisingly, Al-Gharibi (2008) found that Omani students did not perceive social studies as useful for career opportunities. They ranked English language, mathematics, and science as important subjects for careers. Overall, social studies as often described in literature appears to be a marginalized school subject (Bolick, Adams, \& Willox, 2010; Burstein, Hutton, \& Curtis, 2006; Leming, et al, 2006; McGuire, 2007). As Bolick et al. (2010, p. 2) argued, "[t]he state of social studies in [American] public elementary school classrooms reflects the current atmosphere of high-stakes testing in the nation's schools. That is, it is marginalized and narrowed in the classroom".

\section{Conclusion}

The current study provided insights into some aspects of social studies in Omani schools in the current reform. From our data, it appears that teachers had positive views on the importance of social studies in developing citizenship. At the same time, they appeared to implement a wide range of instructional methods that help students participate effectively in learning situations. However, the study identified some areas that need attention. First, social studies curriculum appears to be dominated by topics that focus on Oman. It is important that social studies should focus on a wide range of topics, including global issues and perspectives. Second, teachers reported having very limited opportunities to participate in professional development activities. The Ministry of Education should offer a wide range of in-service professional development opportunities that meet teachers' professional needs. Finally, given the importance of social studies, it received a low ranking rate in schools. Specific measures to address this issue are needed.

\section{References}

Adeyinka, A. A. (2000). Philosophical foundations of socials studies education in Africa. In M. B. Adeyemi (Ed.), Social studies in African education (pp. 13-24). Gaborone, Botswana: Pyramid Publishers.

Al-Gharibi, Z. M. (2008). Attitudes related to social studies with young adolescents in the Sultanate of Oman. Unpublished master's thesis, University of Glasgow, United Kingdom. Retrieved from http://theses.gla.ac.uk/568/01/2008Al-Gharibimsc(r).pdf

Al-Hamdi, M. (2013). The level of applying historical thinking skills in teaching history curricula in post-basic education schools in the Sultanate of Oman. Unpublished master's thesis [In Arabic], Sultan Qaboos University, Al-Khodh, Oman.

AlMaamari, S. N. (2009). Citizenship education in initial teacher education in the Sultanate of Oman: An exploratory study of the perceptions of student teachers of social studies and their tutors. Unpublished doctoral dissertation, University of Glasgow, Scotland, United Kingdom. Retrieved from http://theses.gla.ac.uk/1081/01/2009saifphd.pdf

Al-Malki, L. (2013). The employment degree of critical thinking skills by social studies teachers in the post-basic education in the Sultanate of Oman. Unpublished master's thesis [In Arabic], Sultan Qaboos University, Al-Khodh, Oman.

Al-Nofli, M. A. (2010). Students' perceptions about geography: A study of basic education school students in Oman. European Journal of Social Sciences, 16(1), 11-20.

Al-Nofli, M. A. (2013). The state of geography in basic education schools in Muscat, Oman. International Research in Geographical and Environmental Education, 2(2), 109-119. http://dx.doi.org/10.1080/10382046.2013.778711

Al-Rabani, A. H. (2009). Global issues in Omani social studies textbooks (grades 3-12) [In Arabic]. Journal of Educational \& Psychological Studies, 3(1), 1-23.

Al-Riyami, S. N. (1996). The status of geographic education in the secondary schools of Oman. Unpublished doctoral dissertation, University of Pittsburgh, Pennsylvania.

Al-Sarmi, B. A. (2012). The reality of education for global citizenship in the Sultanate of Oman from social studies teachers' perspectives. Unpublished master's thesis [In Arabic], Sultan Qaboos University, Al-Khodh, Oman.

Bolick, C. M., Adams, R. L., \& Willox, L. (2010). The marginalization of elementary social studies in teacher education. Social Studies Research \& Practice, 5(1), 1-22.

Bouazza, A., \& Al-Mufaraji, M. N. (2005). Use of school libraries by teachers: A case study of Oman. Libri, 55, 140-147. http://dx.doi.org/10.1515/LIBR.2005.140

Burstein, J. H., Hutton, L. A., \& Curtis, R. (2006). The state of elementary social studies teaching in one urban 
district. Journal of Social Studies Research, 30(1), 15-20.

Engle, S. H., \& Ochoa, A. S. (1988). Education for democratic citizenship: Decision-making in the social studies. New York: Teachers' College Press.

Leming, J. S., Ellington, L., \& Schug, M. (2006). The state of social studies: A national random survey of elementary and middle school social studies teachers. Social Education, 70(5), 322-327.

McGuire, M. (2007). What happened to social studies? The disappearing curriculum. Phi Delta Kappan, 88(8), 620-624.

Ministry of Education. (2005). Teacher's guidebook for social studies: Grade five [In Arabic]. Muscat: Author.

Ministry of Education. (2006). From access to success: Education for all [EFA] in the Sultanate of Oman 1970-2005. Muscat: Author.

Ministry of Education. (2007). Document of social studies curricula for grades 3-12. Unpublished manuscript [In Arabic].

Ministry of Education. (2009). Geography and modern technologies: Grade 12 [In Arabic]. Muscat: Author.

Ministry of Education. (2011). The annual educational statistical book: 2010/2011. Muscat: Author.

Ministry of Education. (2012). Education in Oman: The drive for quality. Muscat: Author.

National Council for the Social Studies. (1994). Expectations of excellence: Curriculum standards for social studies. Washington, DC: Author.

Print, M., \& Smith, A. (2000). Teaching civic education for a civil, democratic society in the Asian region. Asia Pacific Education Review, 1(1), 101-109. http://dx.doi.org/10.1007/BF03026150

Sears, A. (1994). Social studies as citizenship education in English Canada: A review of research. Theory and Research in Social Education, 22(1), 6-43. http://dx.doi.org/10.1080/00933104.1994.10505714

\section{Copyrights}

Copyright for this article is retained by the author(s), with first publication rights granted to the journal.

This is an open-access article distributed under the terms and conditions of the Creative Commons Attribution license (http://creativecommons.org/licenses/by/3.0/). 